\title{
Effect of Bagging on Chemical Properties of Mango (Mangifera indica L.) cv. Alphonso
}

\author{
Nagaharshitha D*, Khopkar RR, Haldankar PM, Haldavanekar PC and Parulekar YR \\ Department of Horticulture, College of Agriculture, Dr. B. S. Konkan Krishi Vidyapeeth, Dapoli- 415712, Dist- Ratnagiri, (M. S.), India
}

*Corresponding author: Nagaharshitha D, Department of Horticulture, College of Agriculture, Dr. B. S. Konkan Krishi Vidyapeeth, Dapoli- 415712, Maharashtra, India, Tel: 02358-282415-217; E-mail: harshi.dmg@gmail.com

Rec date: Mar 5, 2014, Acc date: May 16, 2014, Pub date: May 18, 2014

Copyright: (c) 2014 Nagaharshitha D, et al. This is an open-access article distributed under the terms of the Creative Commons Attribution License, which permits unrestricted use, distribution, and reproduction in any medium, provided the original author and source are credited.

\begin{abstract}
An experiment was conducted to study the effect of bagging on growth and development of mango (Mangifera indica L.) cv. Alphonso in the year 2012 from March to June, undertaken in Randomized Block Design. Mango fruits were subjected to six types of bagging treatments with 3 replications at 60 days after fruit set. Results showed that the chemical parameters such as Moisture content, acidity, TSS, reducing, non-reducing sugars and $\beta$ carotene were not significantly varied due to bagging. Further the total sugars in fruits of muslin cloth and scurting bags were improved at ripe stage over control. The sensory quality in fruits of scurting and muslin cloth bags was improved over control.
\end{abstract}

Keywords: Alphonso; Bagging; Chemical properties; Sensory evaluation

\section{Introduction}

Mango is the most important fruit crop of India. It's delicious taste, exceedingly acceptable flavor, pleasing color and exemplary nutritive value made it 'National fruit of India' and is known as 'King of fruits'. Konkan region of Maharashtra accounts for about 10 per cent of the total area under mango in the country, out of which almost 90 per cent area is covered by the single cultivar "Alphonso", which is locally called as 'Hapus'. It thrives and yields best under warm and humid climate of konkan region. It is specially preferred for export because of its optimum size and shape, attractive golden yellow skin and flesh colour, exemplary flavour and good keeping quality. It is the best variety for both table and processing purpose [1]. In India, as Alphonso is mostly consumed as a table fruit, its external appearance is an important parameter. Attractive fruits fetch premium rate in the market. There are various approaches to improve external appearance of fruit. Bagging of fruit is one of the novel ways among these various means. Bagging is the covering of individual fruit with specially designed paper or cloth bags. Bagging protects fruits from pests, fungal infections, diseases, mechanical damage, reduces spraying of insecticides, and provides an estimate of harvestable fruits per tree. Bagging of fruits is done to prevent damage occurring due to bruises, wounds, scars also diseases, pest attack and to produce cleaner fruit skin with attractive color. In mango, bagging also helps to prevent fruit fly attack and fungal disease incidence. Pre-harvest bagging has shown improvement in the quality of fruits. Further, in recent years the unfavorable climate is often experienced in the Konkan region of Maharashtra which spoil the external appearance of fruit. Thus bagging can be helpful under such conditions. Pre-harvest bagging possess prospectus in Alphonso mango, which is not much attempted and hence, the present study was conducted to study the effect of bagging on chemical properties of mango cv. Alphonso.

\section{Materials and Methods}

The experiment was conducted in the year 2012 in the Indo Israel plot, Department of Horticulture, College of Agriculture Dapoli, Dist. Ratnagiri. The soil of experimental plot is red lateritic with uniform depth with good drainage conditions having $\mathrm{pH}$ ranging from 5.6 to 6.5. The place, Dapoli represents more or less tropical climate having $78 \%$ humidity throughout the year with minimum $18.5^{\circ} \mathrm{C}$ and maximum $30.8^{\circ} \mathrm{C}$ temperature and an average precipitation of 3,500 $\mathrm{mm}$, distributed mainly during four months from June to September. The experiment was arranged in Randomized block design and each treatment was replicated three times and 20 fruits were taken per treatment per replication. Treatment details are as follows: $T_{1}-$ Brown paper bag, $\mathrm{T}_{2}-$ Newspaper bag, $\mathrm{T}_{3}-$ Butter paper bag, $\mathrm{T}_{4}$ - Plastic bag, $\mathrm{T}_{5^{-}}$- Muslin cloth bag, $\mathrm{T}_{6^{-}}$Scurting bag and $\mathrm{T}_{7^{-}}$control. Perforations were made on all bags except for scurting and muslin cloth bags for proper ventilation required for fruit development. Egg sized fruits were selected for bagging. In case of more than two fruits in a cluster, the smaller underdeveloped, deformed fruits, spotted fruits were removed by secator and only 1-2 healthy fruits were bagged. While bagging the brown paper bags, Newspaper bags, butter paper bags and plastic bags were stapled properly, so that it will not fall down as well as there will not be open space for entry of insects or rain etc. The scurting and muslin cloth bags were tied with the help of thread. Observations of chemical parameters were taken at harvest and ripe stages. Sensory score was also recorded at ripe stage. 4 fruits were selected randomly and analyzed to determine the fruit chemical composition (moisture content, TSS, acidity, ascorbic acid, $\beta$ carotene, reducing, non-reducing and total sugars) at harvest and ripe stages according to A.O.A.C [2]. The data obtained was analyzed statistically as per the method suggested by Panse and Sukhatme [3]. The standard error of mean (S.Em.) was worked out and the critical difference (C.D.) at 5 per cent was calculated whenever the results were found significant. 
Citation: Nagaharshitha D, Khopkar RR, Haldankar PM, Haldavanekar PC, Parulekar YR (2014) Effect of Bagging on Chemical Properties of Mango (Mangifera indica L.) cv. Alphonso. Agrotechnol 3: 124. doi:10.4172/2168-9881.1000124

Page 2 of 4

\section{Results and Discussion}

When chemical parameters from the Table 1 are seen, it was observed that moisture content was not significantly affected by bagging at harvest and at ripe stages. However, the highest moisture content was observed in the treatment $\mathrm{T}_{4}(82.10 \%)$, whereas the lowest was observed in the treatment $\mathrm{T}_{2}(80.46 \%)$,at ripe stage the highest moisture content was observed in the treatment $\mathrm{T}_{6}(81.00 \%)$ and the lowest in the treatment $\mathrm{T}_{2}$ (79.10\%). Light is found to effect the quality of fruits [4].

\begin{tabular}{|c|c|c|c|c|c|c|c|c|c|c|c|c|c|c|c|c|}
\hline \multirow[t]{2}{*}{ Treatment } & \multicolumn{2}{|c|}{$\begin{array}{l}\text { Moisture } \\
\text { content(\%) }\end{array}$} & \multicolumn{2}{|l|}{ TSS(oB) } & \multicolumn{2}{|c|}{ Acidity(\%) } & \multicolumn{2}{|c|}{$\begin{array}{l}\text { Ascorbic } \\
\text { acid(mg/100 } \\
\mathrm{gm})\end{array}$} & \multicolumn{2}{|c|}{$\begin{array}{l}\text { Reducing } \\
\text { sugars(\%) }\end{array}$} & \multicolumn{2}{|c|}{$\begin{array}{l}\text { Non reducing } \\
\text { sugars(\%) }\end{array}$} & \multicolumn{2}{|c|}{$\begin{array}{l}\text { Total } \\
\text { sugars(\%) }\end{array}$} & \multicolumn{2}{|c|}{$\begin{array}{l}\beta \text { carotene }(\mu \mathrm{g} / 100 \\
\mathrm{g} \text { of pulp) }\end{array}$} \\
\hline & $\begin{array}{l}\text { At } \\
\text { harvest }\end{array}$ & $\begin{array}{l}\text { At } \\
\text { ripe }\end{array}$ & $\begin{array}{l}\text { At } \\
\text { harvest }\end{array}$ & $\begin{array}{l}\text { At } \\
\text { ripe }\end{array}$ & $\begin{array}{l}\text { At } \\
\text { harvest }\end{array}$ & $\begin{array}{l}\text { At } \\
\text { ripe }\end{array}$ & $\begin{array}{l}\text { At } \\
\text { harvest }\end{array}$ & $\begin{array}{l}\text { At } \\
\text { ripe }\end{array}$ & $\begin{array}{l}\text { At } \\
\text { harvest }\end{array}$ & $\begin{array}{l}\text { At } \\
\text { ripe }\end{array}$ & $\begin{array}{l}\text { At } \\
\text { harvest }\end{array}$ & $\begin{array}{l}\text { At } \\
\text { ripe }\end{array}$ & $\begin{array}{l}\text { At } \\
\text { harvest }\end{array}$ & $\begin{array}{l}\text { At } \\
\text { ripe }\end{array}$ & $\begin{array}{l}\text { At } \\
\text { harvest }\end{array}$ & At ripe \\
\hline $\begin{array}{l}\text { T1 (Brown } \\
\text { paper bag) }\end{array}$ & 81.63 & 79.70 & 8.22 & 14.64 & 3.65 & 0.39 & 78.20 & 52.77 & 1.82 & 3.82 & 1.08 & 9.98 & 2.90 & 13.80 & 304.40 & 11132.00 \\
\hline $\begin{array}{l}\text { T2 (News } \\
\text { paper bag) }\end{array}$ & 80.46 & 79.10 & 8.17 & 15.96 & 3.65 & 0.41 & 78.11 & 52.00 & 1.80 & 3.85 & 1.11 & \begin{tabular}{|l|}
10.1 \\
\end{tabular} & 2.90 & 13.96 & 303.63 & 11114.67 \\
\hline $\begin{array}{l}\text { T3 (Butter } \\
\text { paper bag) }\end{array}$ & 80.63 & 80.43 & 8.19 & 15.47 & 3.69 & 0.39 & 78.97 & 52.20 & 1.82 & 3.86 & 1.14 & \begin{tabular}{|l|}
10.04 \\
\end{tabular} & 2.95 & 13.90 & 306.00 & 11426.00 \\
\hline $\begin{array}{l}\text { T4 (Plastic } \\
\text { bag) }\end{array}$ & 82.10 & 80.83 & 8.27 & 15.87 & 3.63 & 0.40 & 79.43 & 52.00 & 1.85 & 3.92 & 1.17 & \begin{tabular}{|l|}
10.18 \\
\end{tabular} & 3.02 & 14.10 & 318.73 & 11864.33 \\
\hline $\begin{array}{l}\text { T5(Muslin } \\
\text { cloth bag) }\end{array}$ & 81.90 & 80.73 & 8.34 & 15.18 & 3.62 & 0.38 & 78.87 & 52.80 & 1.87 & 3.93 & 1.2 & 10.32 & 3.07 & 14.25 & 312.53 & 11588.00 \\
\hline $\begin{array}{l}\text { T6 } \\
\text { (Scurting } \\
\text { bag) }\end{array}$ & 81.60 & 81.00 & 8.36 & 15.43 & 3.63 & 0.39 & 78.91 & 54.90 & 1.86 & 3.95 & 1.21 & \begin{tabular}{|l|}
10.32 \\
\end{tabular} & 3.07 & 14.27 & 315.87 & 11834.33 \\
\hline $\begin{array}{l}\text { T7 } \\
\text { (control) }\end{array}$ & 81.10 & 80.80 & 8.37 & 15.45 & 3.61 & 0.40 & 78.98 & 54.17 & 1.88 & 3.95 & 1.19 & \begin{tabular}{|l|}
10.29 \\
\end{tabular} & 3.07 & 14.24 & 318.60 & 11880.00 \\
\hline Range & $\begin{array}{l}80.46-8 \\
2.1\end{array}$ & $\begin{array}{l}79.10- \\
81\end{array}$ & $\begin{array}{l}8.17-8 . \\
37\end{array}$ & $\begin{array}{l}14.64- \\
15.96\end{array}$ & $\begin{array}{l}3.61-3 . \\
69\end{array}$ & $\begin{array}{l}0.38-0 \\
.41\end{array}$ & $\begin{array}{l}78.11-7 \\
9.43\end{array}$ & $\begin{array}{l}52-54 . \\
9\end{array}$ & $\begin{array}{l}1.80-1 \\
88\end{array}$ & $\begin{array}{l}3.82- \\
3.95\end{array}$ & $\begin{array}{l}1.08-1 . \\
21\end{array}$ & $\begin{array}{l}9.98-1 \\
0.32\end{array}$ & $\begin{array}{l}2.9-3.0 \\
7\end{array}$ & $\begin{array}{l}13.8-1 \\
4.27\end{array}$ & \begin{tabular}{|l}
$303.63-$ \\
318.73
\end{tabular} & $\begin{array}{l}11114.67- \\
11880\end{array}$ \\
\hline Mean & 81.35 & 80.37 & 8.27 & 15.43 & 3.64 & 0.39 & 78.78 & 52.98 & 1.84 & 3.9 & 1.16 & \begin{tabular}{|l|}
10.18 \\
\end{tabular} & 3.00 & 14.07 & 311.4 & 11548.48 \\
\hline S. Em \pm & 0.566 & 0.504 & 0.054 & 0.34 & 0.021 & 0.013 & 0.122 & 0.842 & 0.013 & 0.05 & 0.019 & \begin{tabular}{|l|} 
\\
0.107
\end{tabular} & 0.023 & 0.103 & 1.426 & 358.38 \\
\hline $\begin{array}{l}\text { C. D. at } \\
5 \%\end{array}$ & NS & NS & NS & NS & NS & NS & 0.376 & NS & 0.04 & NS & 0.058 & NS & 0.073 & 0.319 & 4.396 & NS \\
\hline
\end{tabular}

Table 1: Effect of bagging on physico chemical properties of mango cv. Alphonso.

These results are in line with results obtained by Ding and Syakirah [5] in mango fruit. TSS was not varied significantly due to bagging at harvest and at ripe stages. At harvest, the highest TSS was observed in $\mathrm{T}_{7}\left(8.37^{\circ} \mathrm{B}\right)$, whereas the lowest was observed in $\mathrm{T}_{2}\left(8.17^{\circ} \mathrm{B}\right)$. At ripe stage, the highest TSS was noticed in $\mathrm{T}_{2}\left(15.96^{\circ} \mathrm{B}\right)$.

The lowest was noticed in $\mathrm{T}_{1}\left(14.64^{\circ} \mathrm{B}\right)$. Similarly there was nonsignificant variation between different treatments in acidity (\%) of Alphonso mango fruits at harvest and at ripe stages. At harvest, the highest acidity (\%) was observed in the treatment $\mathrm{T}_{3}(3.69 \%)$ whereas the lowest was recorded in the treatment $\mathrm{T}_{7}(3.61 \%)$. At ripe stage, the highest acidity (\%) was noticed in $\mathrm{T}_{2}(0.41 \%)$. The lowest was recorded in $\mathrm{T}_{5}(0.38 \%)$. At harvest, ascorbic acid was significantly varied. It was the highest in the treatment $\mathrm{T}_{4}(79.43 \mathrm{mg} / 100 \mathrm{~g})$ which was significantly superior to all other treatments. The lowest was noticed in $\mathrm{T}_{2}(78.11 \mathrm{mg} / 100 \mathrm{~g})$. At ripe stage there was non-significant variation in ascorbic acid content between different treatments. However, the highest ascorbic acid content was noticed in the treatment $\mathrm{T}_{6}(54.90$ $\mathrm{mg} / 100 \mathrm{~g}$ ) whereas the lowest ascorbic acid

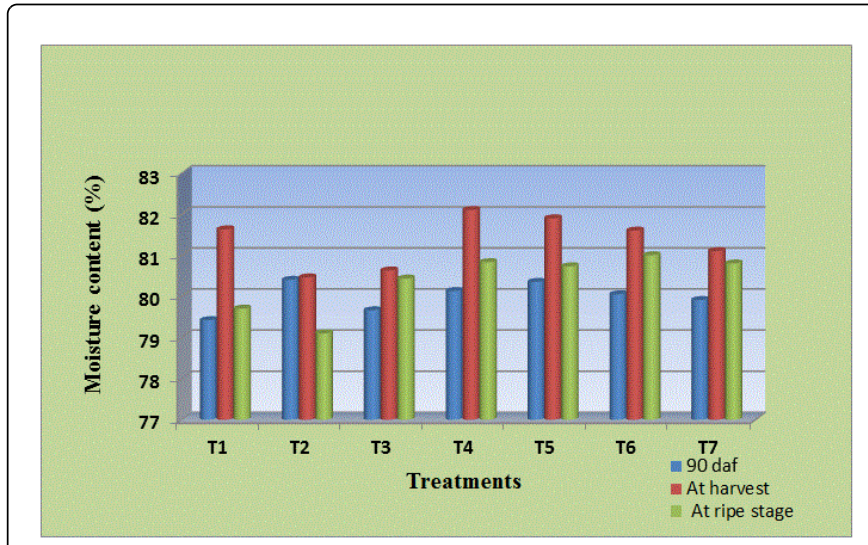

Figure 1: Effect of bagging on moisture content (\%) of fruits in mango cv. Alphonso. 


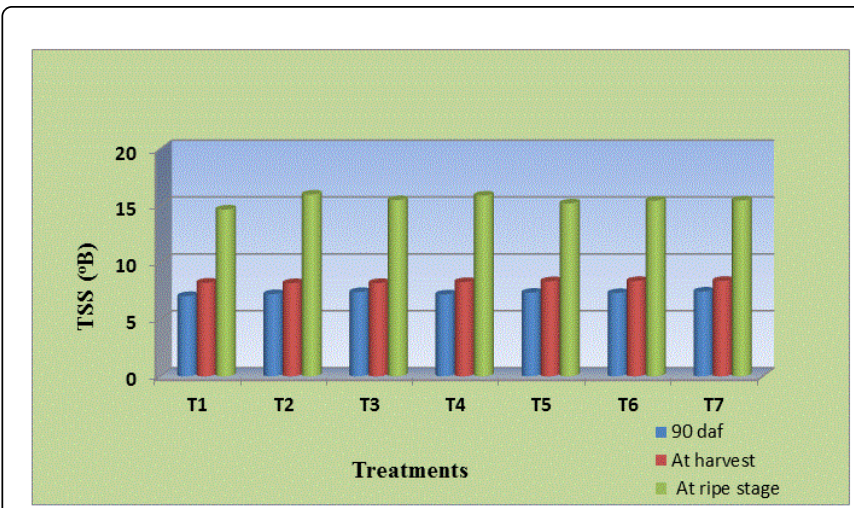

Figure 2: Effect of bagging on TSS $\left({ }^{\circ} \mathrm{B}\right)$ of fruits in mango $\mathrm{cv}$. Alphonso.

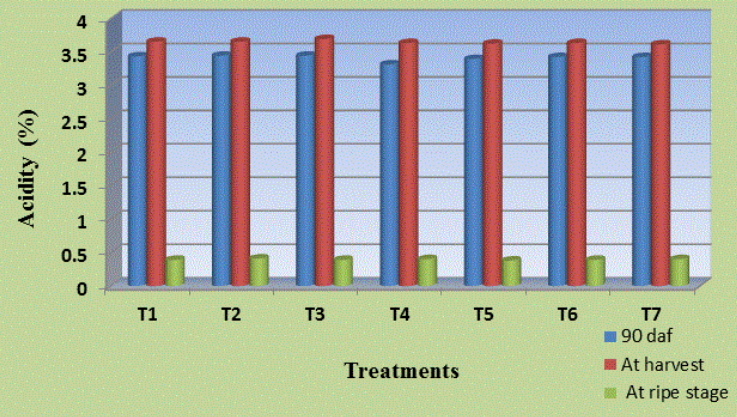

Figure 3: Effect of bagging on acidity (\%) of fruits in mango cv. Alphonso.

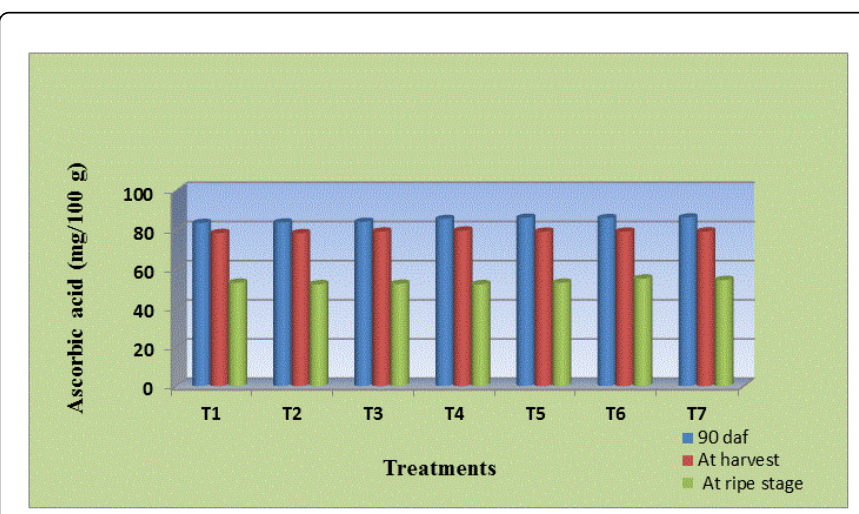

Figure 4: Effect of bagging on ascorbic acid (mg/100 g) content of fruits in mango cv. Alphonso.

content was found in $\mathrm{T}_{2}$ and $\mathrm{T}_{4}(52 \mathrm{mg} / 100 \mathrm{~g})$ treatments. At harvest stage, the reducing sugar (Figures 1-5) was significantly varied.

The highest reducing sugar was in the treatment $\mathrm{T}_{7}(1.88 \%)$. The lowest reducing sugar was noticed in the treatment $\mathrm{T}_{2}(1.80 \%)$. At ripe stage there was non-significant variation between different treatments in reducing sugars. However, the highest was noticed in the treatments $\mathrm{T}_{6}(3.95 \%)$ and $\mathrm{T}_{7}$ (3.95\%). The lowest was noticed in the treatment $\mathrm{T}_{1}$ (3.82\%). Harhash and Al-obeed [6] reported in date palm that highest reducing sugars was in blue color bag (27.69\%) compared to control $(23.33 \%)$. Non reducing sugars were significantly varied due to bagging at harvest stage. At harvest stage, the non-reducing sugars (\%) were the highest in the treatment $\mathrm{T}_{6}(1.21 \%)$. It was the lowest in the treatment $\mathrm{T}_{1}(1.08 \%)$. At ripe stage, non-reducing sugars was not significantly varied. The highest was noticed in treatments $\mathrm{T}_{5}$ and $\mathrm{T}_{6}$ $(10.32 \%)$. The lowest non reducing sugars were observed in the treatment $\mathrm{T}_{1}$ (9.98\%). Harhash and Al-Obeed [6] reported that date palm fruit bagged with blue paper bag showed the highest non reducing sugars (33.95\%) as compared to control (30.67\%).

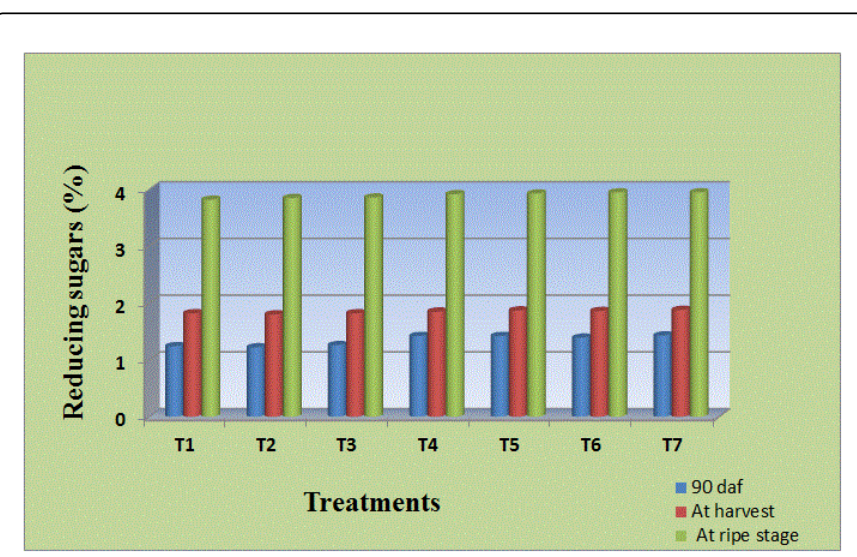

Figure 5: Effect of bagging on reducing sugars (\%) of fruits in mango cv. Alphonso.

At harvest and at ripe stages the total sugars was significantly varied. At harvest it was the highest in treatments $\mathrm{T}_{5}, \mathrm{~T}_{6}, \mathrm{~T}_{7}(3.07 \%)$. It was the lowest in treatments $\mathrm{T}_{1}$ and $\mathrm{T}_{2}(2.9 \%)$. At ripe stage, the total sugars were the highest in the treatment $\mathrm{T}_{6}(14.27 \%)$. It was the lowest in the treatment $\mathrm{T}_{1}(13.80 \%)$. Earlier, Harhash and Al-obeed [6] reported that date palm fruit bagged with blue color bag showed the highest total sugars (61.64\%) as compared to control (54\%).At harvest, the $\beta$-carotene was significantly varied. It was the highest in the treatment $\mathrm{T}_{4}(318.73 \mu \mathrm{g})$ and the lowest in the treatment $\mathrm{T}_{2}(303.63$ $\mu \mathrm{g})$.

\begin{tabular}{|l|l|l|l|l|}
\hline \multicolumn{2}{|l|}{ Treatments } & \multicolumn{2}{|l|}{ Sensory score for } & $\begin{array}{l}\text { Average } \\
\text { score }\end{array}$ \\
\cline { 2 - 5 } & Colour & Flavor & Texture & \\
\hline $\begin{array}{l}\text { T1 (Brown paper } \\
\text { bag) }\end{array}$ & 7.14 & 6.94 & 7.04 & 7.04 \\
\hline $\begin{array}{l}\text { T2 (Newspaper } \\
\text { bag) }\end{array}$ & 7.34 & 7.21 & 7.34 & 7.30 \\
\hline $\begin{array}{l}\text { T3 (Butter paper } \\
\text { bag) }\end{array}$ & 7.00 & 7.15 & 7.00 & 7.05 \\
\hline $\begin{array}{l}\text { T4 (Plastic bag) } \\
\text { T5 (Muslin cloth }\end{array}$ & 7.50 & 7.40 & 7.56 & 7.49 \\
\hline bag) & 7.54 & 7.40 & 7.71 \\
\hline \begin{tabular}{l} 
T6 (Scurting bag) \\
\hline
\end{tabular} & 7.60 & 8.30 & 7.24 & 7.71 \\
\hline
\end{tabular}


Citation: Nagaharshitha D, Khopkar RR, Haldankar PM, Haldavanekar PC, Parulekar YR (2014) Effect of Bagging on Chemical Properties of Mango (Mangifera indica L.) cv. Alphonso. Agrotechnol 3: 124. doi:10.4172/2168-9881.1000124

Page 4 of 4

\begin{tabular}{|l|l|l|l|l|}
\hline T7 (control) & 7.40 & 7.40 & 7.10 & 7.30 \\
\hline Range & $7.00-8.20$ & $6.94-8.30$ & $7.00-7.56$ & $7.04-7.71$ \\
\hline Mean & 7.45 & 7.42 & 7.24 & 7.37 \\
\hline S. Em \pm & 0.101 & 0.131 & 0.134 & 0.156 \\
\hline C. D. at 5\% & 0.312 & 0.404 & NS & 0.481 \\
\hline
\end{tabular}

the treatment $\mathrm{T}_{6}$. Fruits of the treatment $\mathrm{T}_{6}$ showed the highest score and it was in the class of 'Like very much'. Similar to that of color, the sensory score of the texture was around 7 in all the treatments. Thus it indicated that texture of the fruits was in the class of 'Like moderately'.

Table 2: Effect of bagging on sensory evaluation in fruits of mango cv. Alphonso.

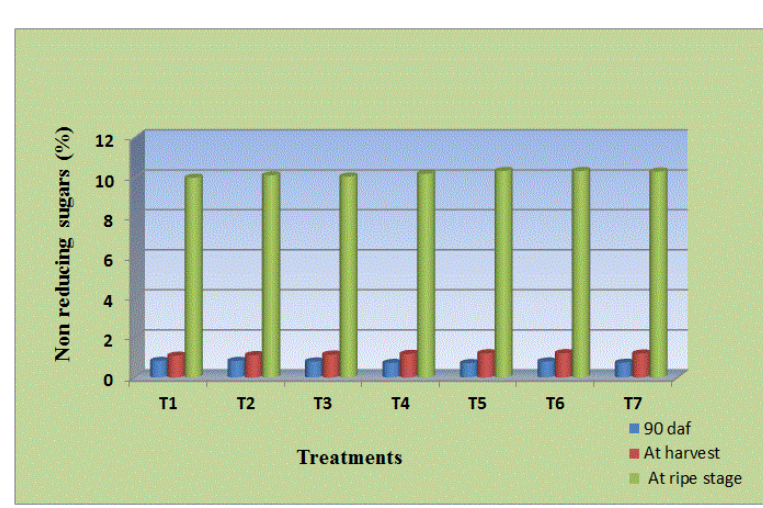

Figure 6: Effect of bagging on non-reducing sugars (\%) of fruits in mango cv. Alphonso.

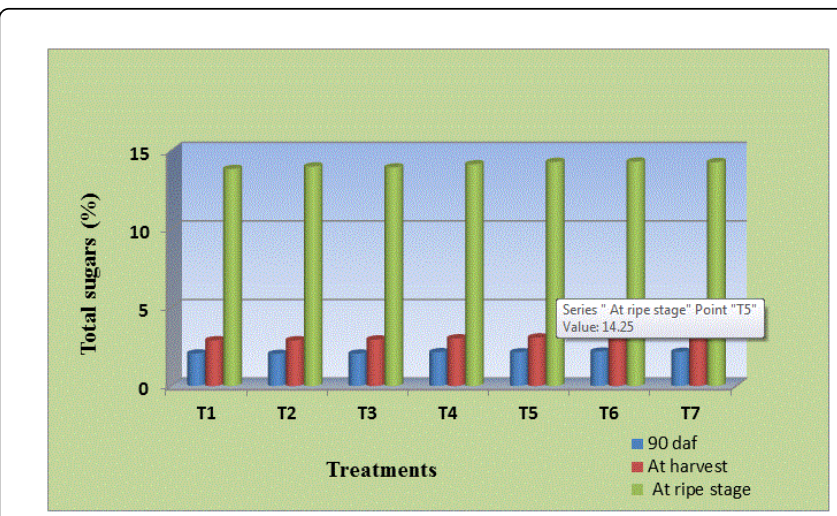

Figure 7: Effect of bagging on total sugars (\%) of fruits in mango cv. Alphonso.

At ripe stage the variation noticed between different treatments for $\beta$-carotene was non-significant. The highest $\beta$-carotene was recorded in the treatment $\mathrm{T}_{7}(11880 \mu \mathrm{g})$. The lowest $\beta$-carotene was noticed in the treatment $\mathrm{T}_{2}(11114.67 \mu \mathrm{g})$. While observing the color of the bagged fruits from the Table 2, it was observed that all the treatments showed the class of 'Like moderately' except the treatment $T_{5}$. Fruits bagged with the treatment $T_{5}$ had the fruits in the class of 'Like very much'. While comparing the sensory score of flavor (Figures 6-9), all the treatments having the same class i.e. 'Like moderately' class except

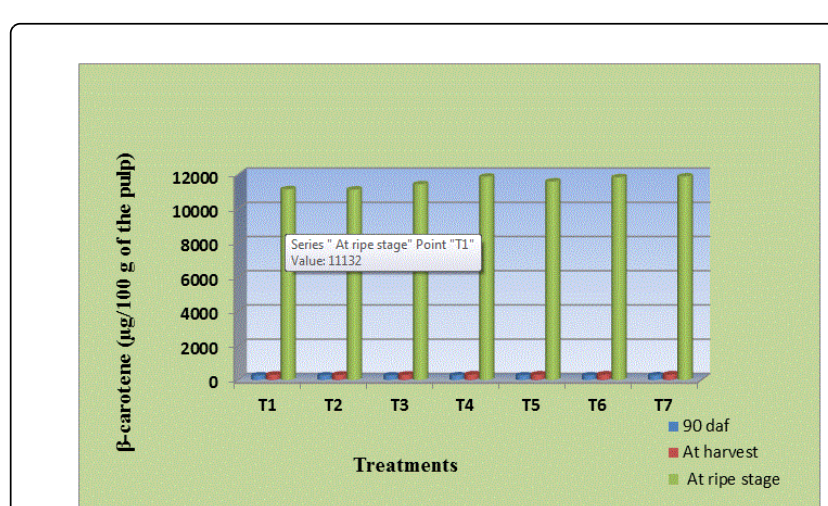

Figure 8: Effect of bagging on $\beta$-carotene ( $\mu \mathrm{g} / 100 \mathrm{~g}$ of pulp) of fruits in mango cv. Alphonso.

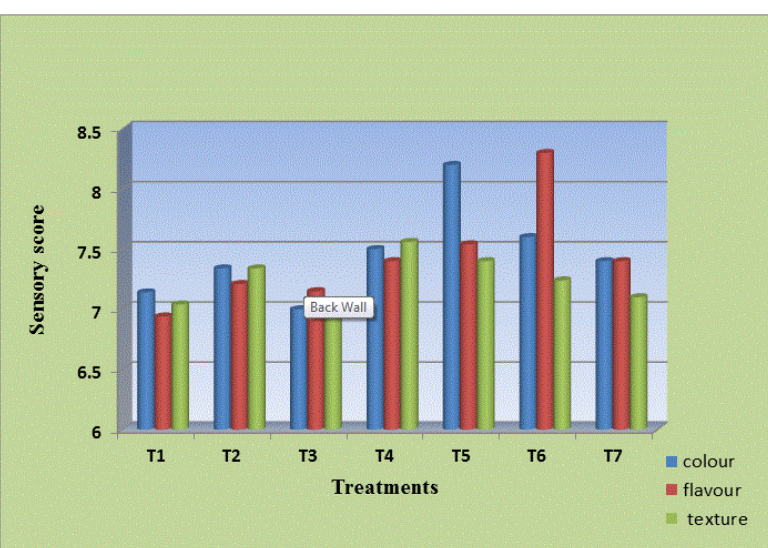

Figure 9: Effect of bagging on sensory score of fruits in mango cv. Alphonso.

\section{References}

1. Cheema GS, Dani PC (1934) Report on the export of mangoes to Europe, Dept. of Agril, Bombay Bull, 170.

2. AOAC (1975) Official Methods of Analysis. Association of Official Analytical Chemists, 12th Edition, Washington DC, 20044.

3. Panse VG, Sukhatme PV (1985) Statistical methods for Agricultural Workers. ICAR Rev. Edition: 97-156.

4. Anonymous (2005) A text book of fruit production, Aman Publishing House, Meerut: 8.

5. Ding P, Syakirah MN (2010) Influence of fruit bagging on post-harvest quality of 'Haruminus' mango. Acta Horticulturae 877: 169-174.

6. Harhash MM, Al-Obeed RS (2010) Effect of Bunch Bagging Color on Yield and Fruit Quality of Date Palm. American-Eurasian J. Agric. \& Environ. Sci 7: 312-319. 